\title{
Coupled Electrochemical-Thermal Simulations and Validation of Minichannel Cold-Plate Water-Cooled Prismatic 20 Ah $\mathrm{LiFePO}_{4}$ Battery
}

\author{
Chaithanya Akkaldevi ${ }^{1}$, Sandeep Dattu Chitta ${ }^{1}$, Jeevan Jaidi ${ }^{1, *(\mathbb{D})}$, Satyam Panchal ${ }^{2} \mathbb{D}$, Michael Fowler $^{3} \mathbb{D}$ and \\ Roydon Fraser ${ }^{2}$
}

check for updates

Citation: Akkaldevi, C.; Chitta, S.D.; Jaidi, J.; Panchal, S.; Fowler, M.;

Fraser, R. Coupled

Electrochemical-Thermal Simulations and Validation of Minichannel Cold-Plate Water-Cooled Prismatic 20 Ah $\mathrm{LiFePO}_{4}$ Battery. Electrochem 2021, 2,643-663. https://doi.org/10.3390/ electrochem 2040040

Academic Editor: Masato Sone

Received: 11 October 2021

Accepted: 18 November 2021

Published: 22 November 2021

Publisher's Note: MDPI stays neutral with regard to jurisdictional claims in published maps and institutional affiliations.

Copyright: (c) 2021 by the authors. Licensee MDPI, Basel, Switzerland. This article is an open access article distributed under the terms and conditions of the Creative Commons Attribution (CC BY) license (https:// creativecommons.org/licenses/by/ $4.0 /)$.
1 Department of Mechanical Engineering, BITS Pilani, Hyderabad Campus, Telangana 500078, India; chaithanya.akkaldevi3@gmail.com (C.A.); shanmukhasandeep98@gmail.com (S.D.C.)

2 Mechanical and Mechatronics Engineering Department, University of Waterloo, Waterloo, ON N2L 3G1 Canada; satyam.panchal@uwaterloo.ca (S.P.); rafraser@uwaterloo.ca (R.F.)

3 Chemical Engineering Department, University of Waterloo, Waterloo, ON N2L 3G1, Canada; mfowler@uwaterloo.ca

* Correspondence: jaidi@hyderabad.bits-pilani.ac.in; Tel.: +91-40-6630-3548

\begin{abstract}
This paper discusses the quantitative validation carried out on a prismatic $20 \mathrm{Ah} \mathrm{LiFePO}_{4}$ battery sandwiched between two minichannel cold-plates with distributed flow having a single Uturn. A two-way coupled electrochemical-thermal simulations are performed at different discharge rates $(1-4 \mathrm{C})$ and coolant inlet temperatures $\left(15-35^{\circ} \mathrm{C}\right)$. The predicted battery voltage response at room temperature $\left(22{ }^{\circ} \mathrm{C}\right)$ and the performance of the Battery Thermal Management System (BTMS) in terms of the battery surface temperatures (maximum temperature, $T_{\text {max }}$ and temperature difference, $\Delta T$ ) have been analyzed. Additionally, temperature variation at ten different locations on the battery surface is studied during the discharge process. The predicted temperatures are compared with the measured data and found to be in close agreement. Differences between the predicted and measured temperatures are attributed to the assumption of uniform heat generation by the Li-ion model (P2D), the accuracy of electrochemical property input data, and the accuracy of the measuring tools used. Overall, it is suggested that the Li-ion model can be used to design the efficient BTMS at the cell level.
\end{abstract}

Keywords: Li-ion battery; BTMS; minichannel cold-plates; C-rates; coolant temperature; COMSOL software

\section{Introduction and Literature}

Global issues such as air pollution and the energy crisis have led to the rapid development of electric vehicles (EVs) in the past decade and a half, and Li-ion batteries (LIBs) are more widely used in EVs than other battery types (Pb-acid, Ni-Cd, Ni-MH). However, the challenges faced with LIBs include the battery cycle life, power, adaptability, and fast charging, which are primarily dependent on the process parameters and operating temperature. To design the suitable BTMS, it is crucial to know the perfect operating conditions for the batteries to work in a highly efficient manner. In recent times, it was shown that the performance of LIBs is affected by the operating temperatures, and hence, an optimum temperature range of 15 to $35^{\circ} \mathrm{C}$ was suggested [1]. At these temperatures, the LIBs are at their maximum capacity and there are minimal degradation effects. For instance, an experimental test showed a $22.5 \%$ increase in discharge time for a constant current discharge at $25^{\circ} \mathrm{C}$ compared to $50{ }^{\circ} \mathrm{C}$ [2]. Different types of Li-ion batteries are used in EVs and they require different thermal cooling designs for an effective thermal management. Additionally, designing an appropriate battery thermal management system (BTMS) design requires a detailed understanding of heat generation, transportation, and 
dissipation at a cell level. The paragraphs below discuss the researchers' recent experimental and theoretical works on the heat generation rates and thermal responses of different LIBs operated at different process and cooling conditions.

The heat generation rate by a stack of four Li-ion titanate $(10 \mathrm{Ah}, 2.3 \mathrm{~V})$ batteries measured at different discharge rates $(1-4 \mathrm{C})$ and ambient temperatures $\left(28-42^{\circ} \mathrm{C}\right)$ shows that the discharge $\mathrm{C}$-rate has a more significant effect than the ambient temperature [3]. The irreversible and reversible heat generations at different discharge rates $(1-5 \mathrm{C})$ of the $10 \mathrm{Ah} \mathrm{LiFePO}_{4}$ battery revealed that the former is relatively more stable than the latter [4]. The measured heat generation rate of $8 \mathrm{Ah} \mathrm{LiMn}_{2} \mathrm{O}_{4}$ battery during charge-discharge cycles taking into account the effect of operating load, SOC, temperature, and aging have shown that the joule heating rises with a decrease in the battery operating temperature, while the heat of reaction does not differ notably [5]. The heat generation rates obtained from overpotential and entropic heats with negligible heat of mixing in a pouch type $45 \mathrm{Ah}$ $\mathrm{LiFePO}_{4}$ battery have shown that the heat generation is higher during discharge than the charge, and hence an effective cooling system is necessary to prevent thermal runaway at C-rates [6]. The electrochemical-thermal model predicted that the voltage and temperature of $\mathrm{LiFePO}_{4}$ battery were compared with the measured data and found that the reaction heat contributes more, followed by the contact resistance heat and the Joule heat [7]. However, the net heat generation rate increases with the decrease in battery ambient temperature. The measured heat generation rate of a prismatic $20 \mathrm{Ah} \mathrm{LiFePO}_{4}$ cell at different ambient conditions $\left(-10\right.$ to $\left.40{ }^{\circ} \mathrm{C}\right)$ and discharge C-rates (0.25-3 C) have shown that the heat generation increases with the decrease in operating temperature [8]. Furthermore, the heat generation rate rises first, then a plateau region, and then further increases with depth-of-discharge (DOD). The heat generation rate of a cylindrical $2.6 \mathrm{Ah} \mathrm{LiFePO}_{4}$ cell was predicted at different C-rates based on the measured battery surface temperature and surface heat flux and using a simple energy balance [9]. The heat generation rates of 19.5 $\mathrm{Ah} \mathrm{LiFePO}_{4}$ cell have shown that the overpotential and voltage difference methods predicted similar results at all SOCs and C-rates [10]. The heat generation rate of prismatic $40 \mathrm{Ah}$ Li-ion NMC cells measured under adiabatic and constant ambient test conditions showed an overall exothermic behavior with the adiabatic test, but an exothermic behavior during discharge and endothermic behavior during charge with ambient test [11].

After understanding heat generation, it is important to understand its effect on the battery in terms of temperature response. The measured heat generation rates of a battery module of cylindrical cells (18650) of Li-ion NiMnC cathode were used in the thermallumped treatment of each cell [12], and the effects of discharge/charge rate, liquid flow rate, and heat exchange contact surface area were analyzed. A coupled electrochemical-thermal model developed using COMSOL software for a $4 \mathrm{Ah} \mathrm{Li-ion} \mathrm{NCA/graphite} \mathrm{battery} \mathrm{has}$ shown that the maximum temperature is in the proximity of tabs and positive current collector and is due to the high ohmic heat generation [13]. Additionally, the absence of tabs resulted in a more uniformity of battery temperature at the bottom. A review of the battery models and thermal management methods has suggested that the Peukert's equation can be used instead of the more complex electrochemical model [14]. An analytical model based on predicted temperature distribution in 1.5 Ah Li-ion NMC (INR18650-15L) batteries subjected to charge-discharge cycles with a rest period has shown a significant temperature difference between the core and surface at the end of 50 cycles [15]. A numerical study on the response of a commercial cylindrical $\mathrm{LiFePO}_{4} / \mathrm{C}$ battery using a $2 \mathrm{D}$ axisymmetric electrochemical-thermal model at different discharge $\mathrm{C}$-rates and controlled ambient conditions has shown a good match between the predicted and measured discharge voltage and battery surface temperatures [16]. The thermal behavior and evolution of electrochemical reactions in a $20 \mathrm{Ah} \mathrm{LiFePO}_{4}$ prismatic battery with the ambient temperature at $25^{\circ} \mathrm{C}$ were studied using single and multi-cell approaches and at different discharge C-rates [17]. The predicted voltage and thermal responses were compared with the measurements and it was stated that the cooling system is indispensable to maintain the battery surface temperature within the permissible range. 
Now, it is important to understand how to control the temperatures achieved after charge/discharge and which method to use in order to reduce the battery temperatures. A review on the performance of battery pack systems with different liquid coolants (water/oil/liquid-metal/nano-fluid) and coolant configurations (internal/external) was discussed [18]. A review presented on the effect of ambient temperatures and cooling technologies for battery thermal management stated that water-cooling had been widely researched and used in BTMS, and cold-plates are used where there is a space constraint [19]. The study on the effectiveness of air and liquid cooling of Li-ion battery packs by comparing the overall heat transfer coefficient of the respective designs has concluded that water-cooling is three times more effective than air for the same rise in battery surface temperature [20]. Single prismatic $20 \mathrm{Ah} \mathrm{LiFePO}_{4}$ cells sandwiched between cold-plates with a single channel and multiple turns were experimentally studied at different $\mathrm{C}$-rates (1-4 C) and coolant inlet temperatures $\left(5-35^{\circ} \mathrm{C}\right)$, and it was found that the maximum battery surface temperature increases with the increase in C-rate as well as coolant inlet temperature [21,22]. A drive cycle test with a battery pack of three $10 \mathrm{Ah} \mathrm{LiFePO}_{4}$ cells in series and sandwiched between cold-plates was conducted at different C-rates (1-4 C) and coolant inlet temperatures $\left(10-40^{\circ} \mathrm{C}\right)$ and found the maximum battery surface temperature below the optimum range at all C-rates [23]. A battery pack of 30 cylindrical cells (18650 LiNCA/C) was simulated using a coupled electrochemical-thermal model and found that the surface temperatures doubled when the coolant flow rate reduced to half [24]. A conjugate heat transfer model developed and used for a pouch type Li-ion battery pack with coolant channels between the batteries has concluded that the coolant flow rate significantly affects the maximum surface temperature at higher C-rates than at lower C-rates. However, the authors assumed an initial temperature profile at the solid-liquid interface rather than calculating the heat generation rate during the discharge process [25]. A simulation study performed on the effectiveness of liquid cooling of $55 \mathrm{Ah} \mathrm{Li-ion} \mathrm{battery} \mathrm{with} \mathrm{different}$ configurations ( $1 \times 4$ to $4 \times 4$ channels), flow rates $(0.2$ to $1 \mathrm{~L} / \mathrm{min})$, and flow direction has shown increased cooling performance with the increase in the number of channels as well as with all inlets and outlets on one side of the battery [26]. A simulation study performed on cylindrical Li-ion batteries (18650) with coolant pipe placed between the spiral fins has shown a significant drop in maximum battery temperature and temperature difference across the battery by varying the fin height [27]. A 3D thermal model study on a battery module of $7 \mathrm{Ah} \mathrm{Li-ion} \mathrm{batteries} \mathrm{sandwiched} \mathrm{between} \mathrm{aluminum} \mathrm{cold-plates} \mathrm{and}$ discharged at a $5 \mathrm{C}$ discharge rate has revealed that the coolant flow direction towards the electrode showed the best performance, and the coolant mass flow rate has a significant effect on the battery temperatures up to a particular value only [28]. The electrochemicalthermal models developed for prismatic $20 \mathrm{Ah} \mathrm{LiFePO}_{4}$ cells using COMSOL Multiphysics software have shown that the multi-layer approach-based model predictions are in very good agreement with the experiments than the single layer approach [29]. A review comparing uncoupled and coupled battery models stated that the lack of precise experimental data of several parameters in real-time conditions and simplified assumptions such as constant and uniform properties made the electrochemical model (P2D) qualitative [30]. Therefore, the predicted peak temperature and the temperature difference cannot match the measured data. However, the P2D model parameters were taken from the literature as well as physical testing of the battery electrodes. The authors suggested that the model could be scaled up to simulate a battery pack. 
It can be noted from the above-detailed literature survey on the experimental and theoretical research works carried out that there are interesting numerical works based on liquid cooling of Li-ion batteries. Nevertheless, the validation is carried out chiefly in terms of voltage profile and maximum temperature of the battery. The models developed also need to be tested based on temperature variation with time at different locations on the battery surface, apart from average battery temperature and heat flux. The primary motive of this research is to bridge this gap. In the current research, a prismatic $\mathrm{LiFePO}_{4}$ battery with a nominal capacity of $20 \mathrm{Ah}$ sandwiched between cold-plates with multiple channels containing water flow (i.e., distributed flow) is being considered to investigate the battery thermal response at different discharge $\mathrm{C}$-rates and coolant inlet temperatures. The temperature variation with discharge time is plotted at 10 different locations across the principal surface of the battery and is validated with experimental works to test the reliability of the model parameters and also the model itself. A transient, coupled electrochemical-thermal model has been developed using COMSOL Multiphysics software. The electrical and thermal responses predicted in terms of the voltage-time response, battery surface heating, peak temperatures (hot spots), and temperature difference across the battery have been analyzed and validated with the measured data.

\section{Experimental Test Bench for Battery with Cold-Plates}

As part of a detailed study and quantitative validation of the model predictions, experiments were conducted for voltage and temperature responses by the Battery Thermal Management System (BTMS) during the charge-discharge cycle. A test bench set-up developed for EVs at the University of Waterloo, Canada (as shown in Figure 1) consisting of a Battery Management System (BMS) for charge/discharge process and Thermal Management System (TMS) for heat removal from the prismatic $20 \mathrm{Ah} \mathrm{LiFePO}_{4}$ battery was utilized along with the measured temperature data at selected locations across the principal surface of the battery. Different tools used include a Lambda ZUP20-40-800 for low-voltage supply, a TDI Dynaload 232 50-150-800 for load (current), a MotoTron controller to monitor the voltage, current, and temperature. A separate monitor for LabVIEW and Keithley tools with accessories were also used. Sensors (T-type and K-type) were used for the temperature measurements on the battery principal surfaces, tabs, cold-plates, and at minichannel inlet and outlet. Heat flux sensors were also used. A flow meter was installed at the inlet of the cold-plate(s). The complete assembly (battery and the cold-plates) was sandwiched using $12.7 \mathrm{~mm}$ thick polycarbonate sheets, as shown in Figure 1. Spacers with equal size of the battery are provided to change the distance between polycarbonate and cold-plate for the inlet/outlet fittings. For the whole test, charging was carried out at constant current constant voltage (CCCV) and discharging was carried out at constant current. To ensure proper insulation of the test set-up from its surrounding atmosphere, a compression rig was created consisting of two transparent $12.7 \mathrm{~mm}$ thick polycarbonate sheets enclosing the battery with cold-plates. Bolts were used to tighten the assembly. For further details on the conduct of experiments, see the thesis reports published by Waterloo University [31,32]. 


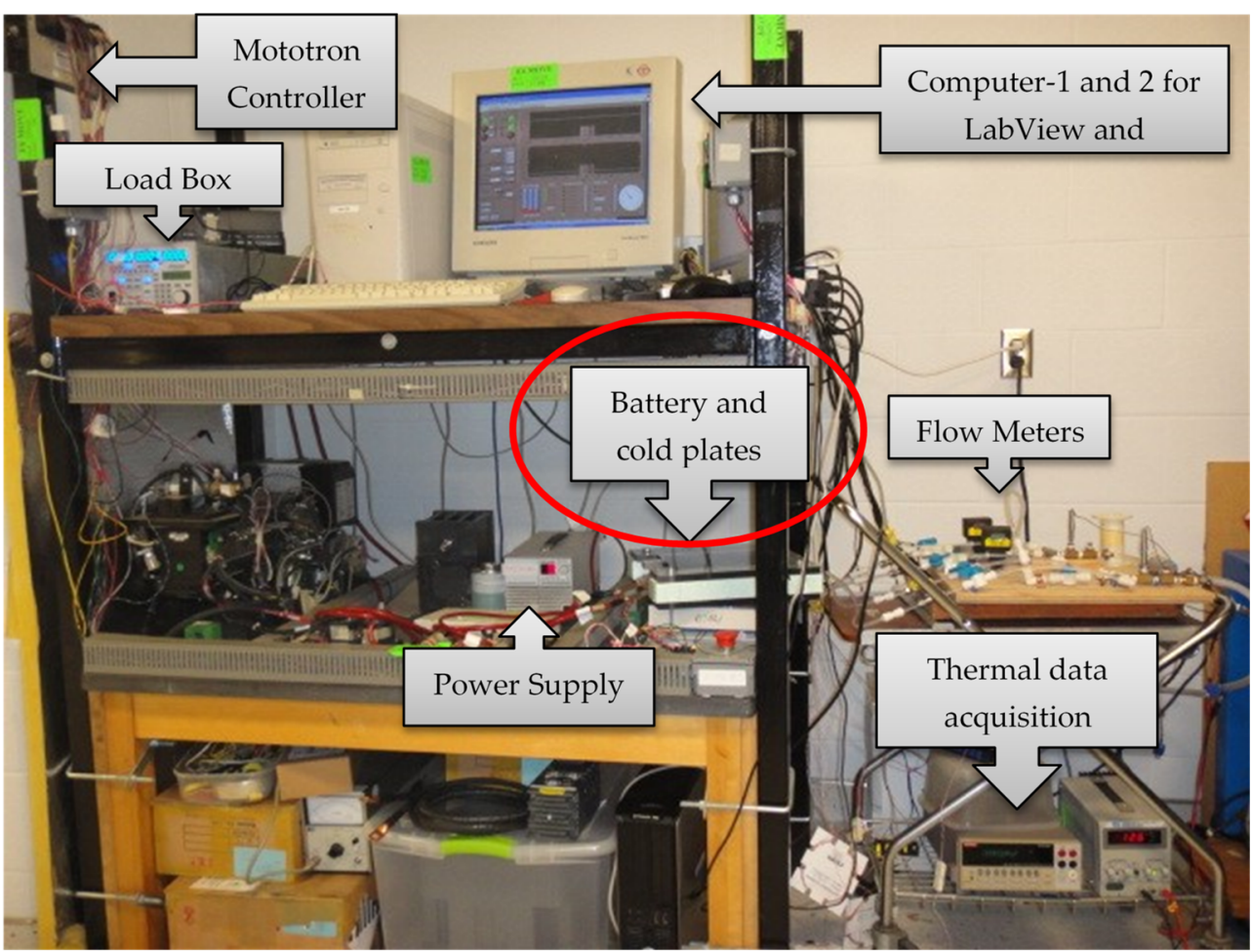

(a)
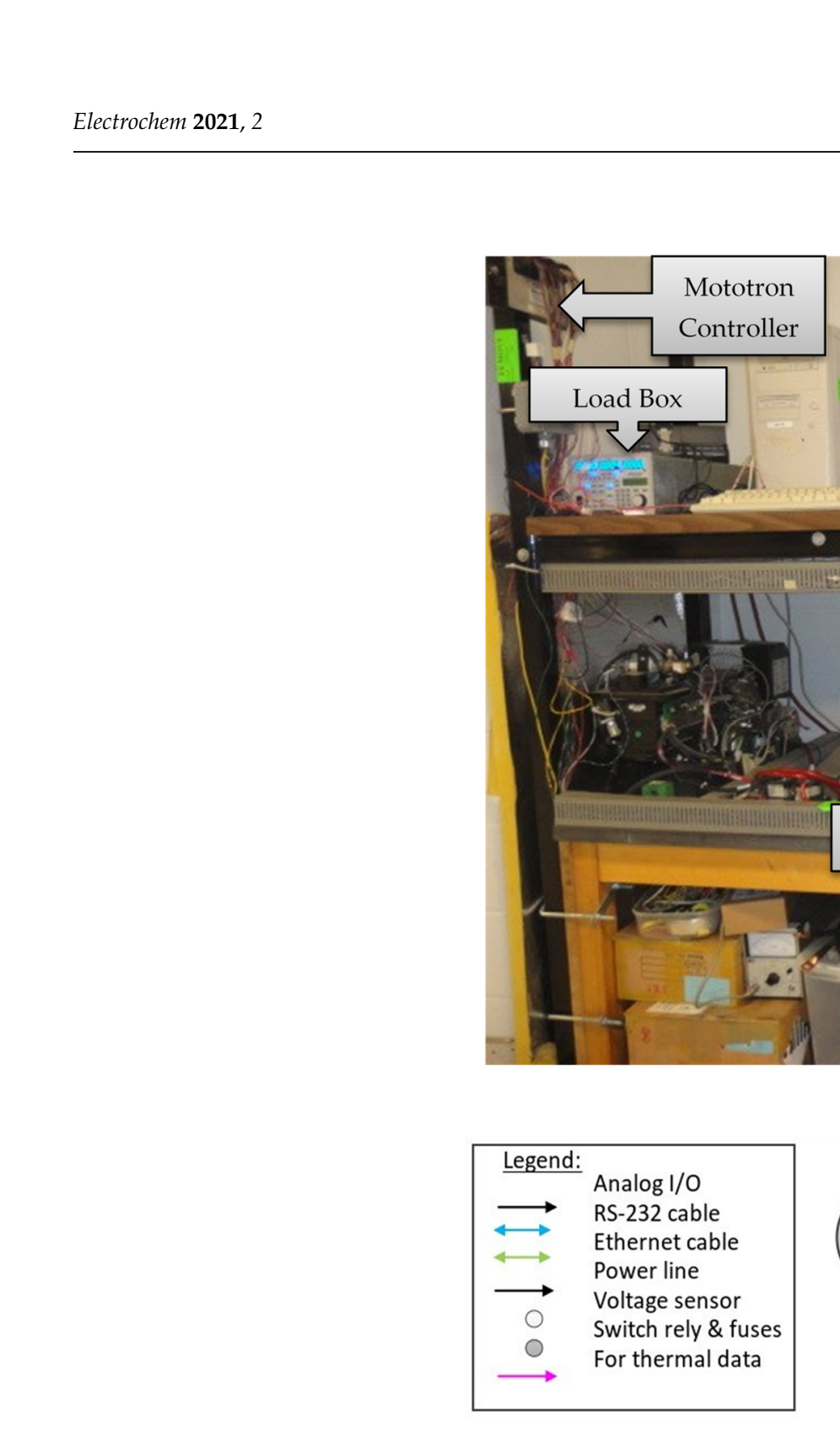

(a)

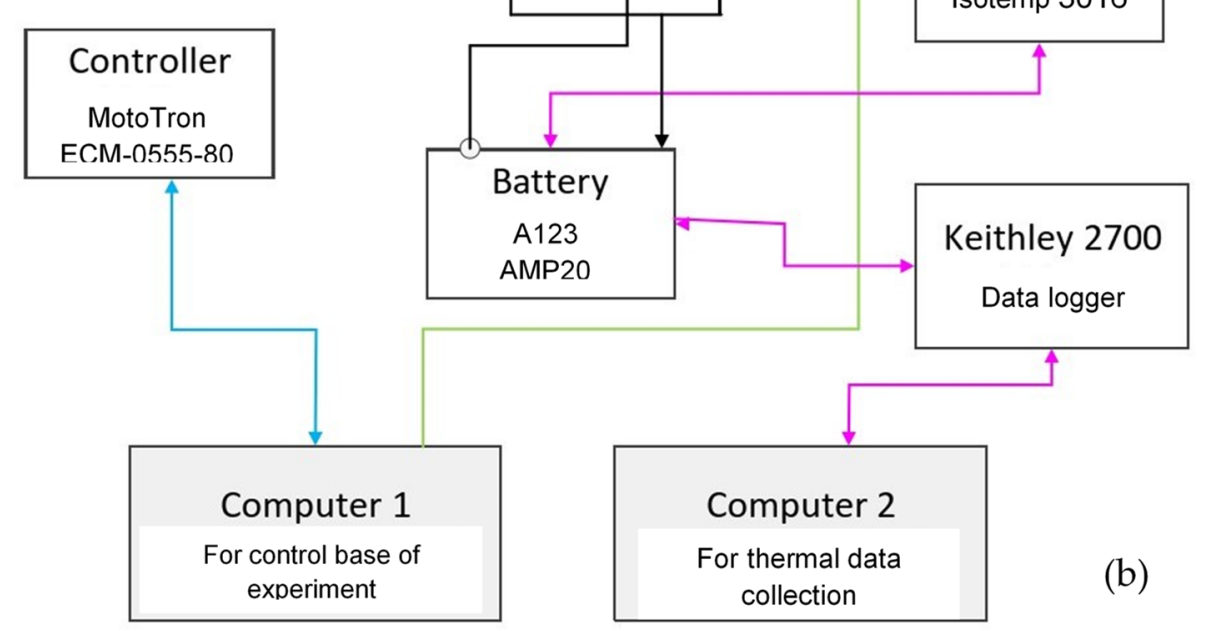

Figure 1. (a) Battery with cold-plates and apparatus (b) schematic of line diagram. 


\section{Mathematical and Numerical Modelling}

The overpotential heat, entropy change heat, and enthalpy of mixing heat are the three primary sources that contribute to the heat generation in Li-ion batteries. However, the heat of mixing is insignificant and can be ignored. In general, the total heat generation is attributed to the overpotential (ohmic and polarization) heat which depends on temperature and current, and the entropy change heat, which depends on state-of-charge (SOC). It has been shown in the literature that considering just entropic and overpotential heats is enough to produce sufficiently accurate results which closely agree with the measured data. An electrochemical-thermal model referred to as the Li-ion battery model is developed and coupled with a 3D conjugate heat transfer model and numerically solved using the COMSOL Multiphysics software. The Li-ion battery model is the most accurate one among the different theoretical models available in the literature. It solves various PDEs and requires many input parameters. However, these parameters are specific to batteries and operating temperatures, and therefore it is practically impossible to measure at every possible condition that the EVs and HEVs operate. Therefore, the use of numerical modelling and simulations tools are very handy and must be adopted to design an efficient Thermal Management System (TMS) once the essential battery parameters are known and/or supplied by the manufacturer. The coupling of the battery model and thermal model (Figure 2) is performed to update the average battery temperature and heat generation. The following subsections discuss the governing equations of each of the models considered in the current research.

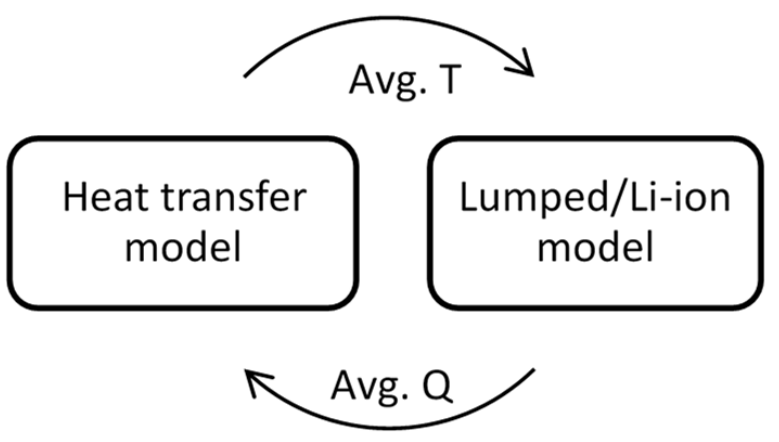

Figure 2. Coupling of battery and thermal models.

\subsection{Li-ion (P2D) Battery Model}

A Li-ion model considers various well-known theories, such as Ohm's law, porous electrode, mass and charge transfer in electrolyte and solid phases, and intercalation/deintercalation kinetics. Therefore, various partial differential equations (PDEs) are required to study these phenomena. The electrochemical process parameters required in the $\mathrm{Li}$-ion battery model include the diffusion coefficient of lithium in the solution and solid phases, the ionic electrical conductivity in the solution phase, the open circuit potential, the entropy coefficient, and the reaction rate [4]. The Li-ion battery model provides four parametersnamely, the solid phase potential $\left(\phi_{s}\right)$, electrolyte phase potential $\left(\phi_{e}\right)$, the concentration of Li-ion in the solid phase $\left(C_{s}\right)$ and concentration of Li-ion in electrolyte phase $\left(C_{e}\right)$ by solving two conservation of charge and two conservation of species equations in the solution and solid phases. Butler Volmer kinetics is used to determine reaction rate and also to couple the above equations. The governing equations are not given here for brevity, but they can be found in the literature $[4,33]$. 


\subsection{Conjugate Heat Transfer Model}

This 3D model is used for the cold-plates with water as coolant, as part of Thermal Management System (TMS). The value of heat generation obtained from the Li-ion model is passed on to the cold-plates through mating surfaces, which are further diffused and dissipated by the coolant flow through the channels. A fixed flow rate is supplied through individual channels, and the flow is laminar for the channel shape and cross-section used. Thus, the 3D conjugate heat transfer model solves the following general transient, incompressible fluid flow, and energy equations;

- Mass conservation equation:

$$
\nabla \cdot V=0
$$

- Momentum conservation equation:

$$
\frac{\partial(\rho V)}{\partial t}+V \cdot \nabla(\rho V)=-\nabla p+\nabla \cdot(\mu \nabla V)
$$

where $V$ is velocity vector, $p$ is pressure, $\rho$ and $\mu$ are density and viscosity of coolant, respectively.

- Energy conservation equation:

$$
\frac{\partial\left(\rho C_{p} T\right)}{\partial t}+V \cdot \nabla\left(\rho C_{p} T\right)=\nabla \cdot(k \nabla T)+\dot{q}_{h}^{\prime \prime \prime}
$$

where $k$ is thermal conductivity, $C_{p}$ is specific heat, $\dot{q}_{h}^{\prime \prime \prime}\left(=Q_{h} / \forall\right)$ is volumetric heat generation rate in the battery, and $\forall$ is battery volume.

The instantaneous average heat generation obtained from the electrochemical (P2D) model is diffused into the cold-plates in the thickness direction and is then carried away by the liquid coolant flowing through the channels. It should be noted here that heat transfer takes place in the battery and cold-plates (as solid domains) as well as in the channels (as a fluid domain). The fluid flow equations are solved using an algebraic multigrid solver, and PARDISO solver is used for heat transfer. The backward differentiation formula (BDF) method is used for time stepping because of its stability and versatility. Furthermore, it can be noted that a stop condition is used to terminate the simulation when the discharge voltage falls below $2.0 \mathrm{~V}$. At high discharge rates, it is observed that the voltage reaches the stop condition before the theoretical discharge time. Hence, there is a difference in actual and theoretical discharge times at $2 \mathrm{C}$ and above.

\subsection{Geometry and Mesh}

The computational domain (geometry model) consists of a commercial prismatic $\mathrm{LiFePO}_{4}$ battery sandwiched between two cold-plates, as shown in Figure 3. The height and width of the battery and the cold-plates are $227 \mathrm{~mm}$ and $157 \mathrm{~mm}$, respectively. The thicknesses of the cold-plates and battery are $1.7 \mathrm{~mm}$ and $7.25 \mathrm{~mm}$, respectively. The crosssection of the channels is hexagonal, and the width is $2 \mathrm{~mm}$. To reduce the computational cost and due to the plane symmetry, only half of the geometry in the thickness direction (i.e., one cold-plate and half of the battery) is considered as the computational domain for the numerical simulations. A tetrahedral mesh is used for the battery and cold-plate, while the hexahedral mesh is used for the tabs. The maximum and minimum element sizes in the fluid domain are $0.625 \mathrm{~mm}$ and $0.25 \mathrm{~mm}$, respectively. Additionally, four layers are used in the near-wall region to resolve boundary flow effects. The mesh elements in the fluid domain and its surrounding solid domains is shown in Figure 4. The present electrochemical (P2D) model requires the material property data of anode (graphite), cathode $\left(\mathrm{LiFePO}_{4}\right)$, and electrolyte (carbonate), and it does not require the property data of a separator. Additionally, the P2D model does account for the tabs. Thus, the thermal model consists of the active battery material and tabs. It can be noted that the tabs are 
heated by the diffusion of heat generated in the battery. The joule heating in the tabs is ignored in the present simulations.

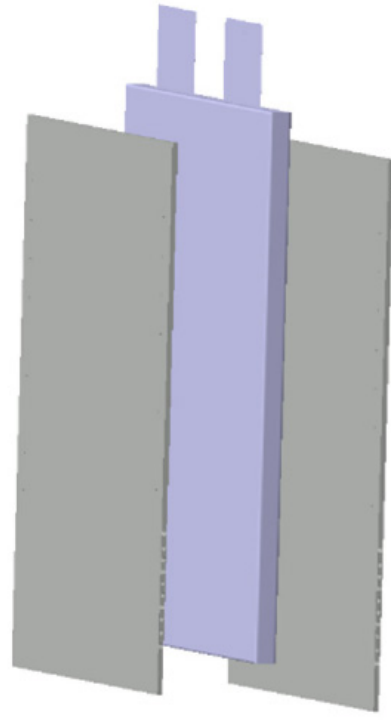

(a)

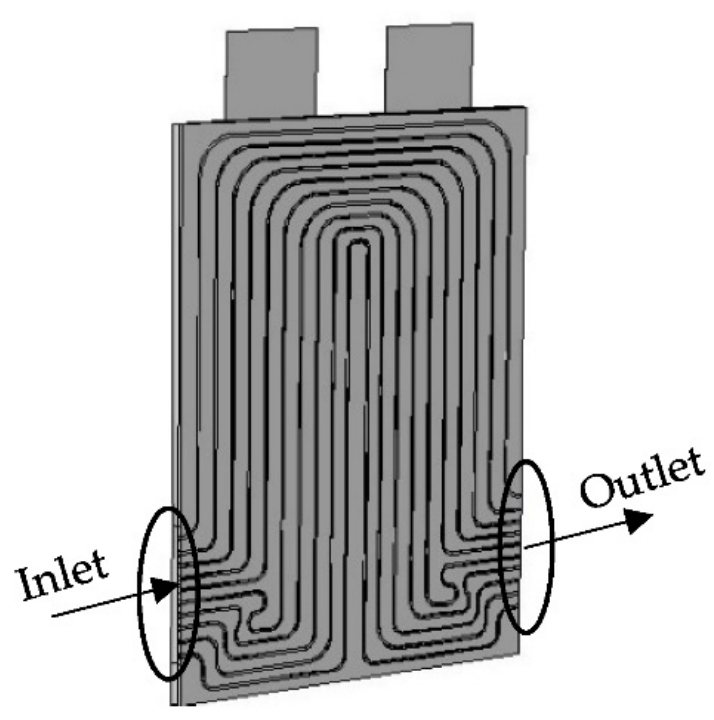

(b)

Figure 3. (a) Exploded view of battery and cold-plates, and (b) cold-plate with minichannels.

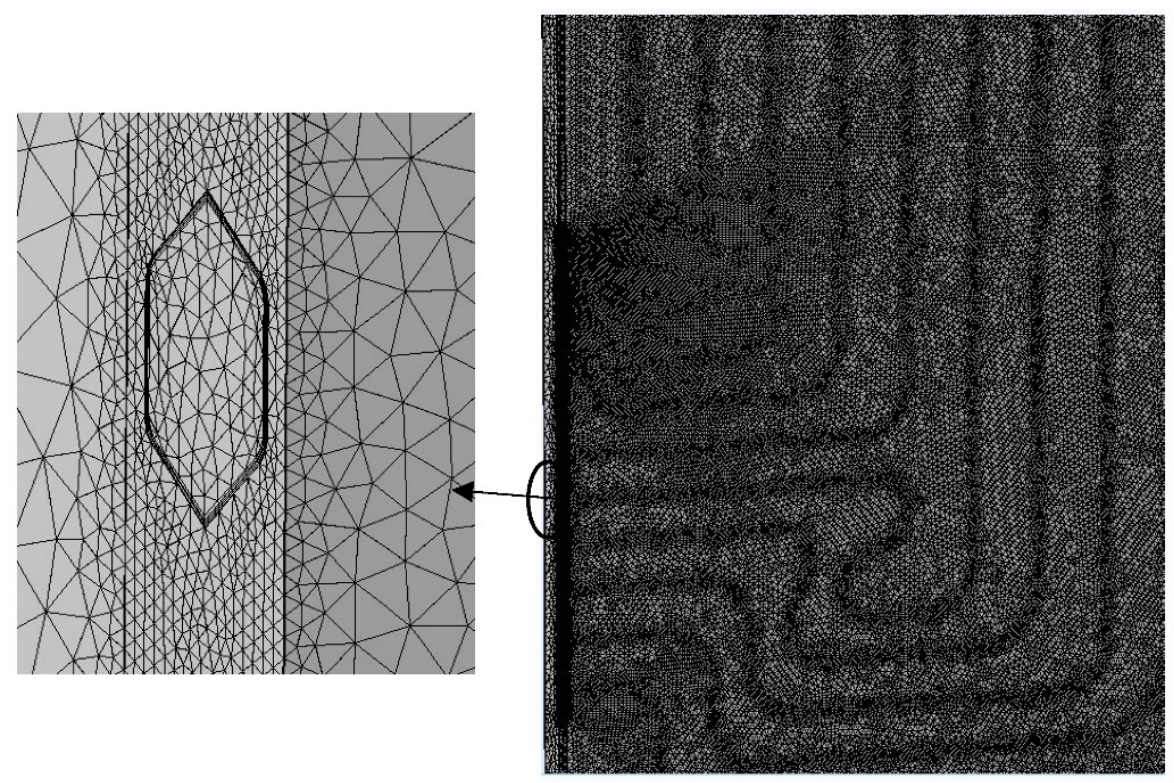

Figure 4. Mesh size variation in all domains (right) with a zoomed view of fluid domain (left). 


\subsection{Grid Independence Study}

A grid independence study has been performed by comparing the maximum temperature on the battery surface and at different discharge C-rates with mesh counts of 3.5, 4.2, and 5.4 million, and the results are shown in Table 1. The mesh refinement is carried out in the fluid domain and resolves the boundary layer effects near the channel wall surfaces. It can be noted that the difference in maximum temperature with 4.2 and 5.4 million mesh counts is insignificant. However, the fine mesh with 5.4 million elements is considered for all case studies because of better convergence, but at the cost of the slight increase in the computational time.

Table 1. Battery temperature vs. mesh element count.

\begin{tabular}{cccc}
\hline \multirow{2}{*}{ Discharge C-Rate } & \multicolumn{3}{c}{ Maximum Surface Temperature $\left({ }^{\circ} \mathrm{C}\right)$} \\
\cline { 2 - 4 } & $\begin{array}{c}\text { 3.5 Million Mesh } \\
\text { Elements }\end{array}$ & $\begin{array}{c}\text { 4.2 Million Mesh } \\
\text { Elements }\end{array}$ & $\begin{array}{c}\text { 5.4 Million Mesh } \\
\text { Elements }\end{array}$ \\
\hline 1 C & 17.00 & 16.75 & 16.74 \\
2 C & 19.90 & 19.56 & 19.50 \\
3 C & 23.82 & 22.67 & 22.65 \\
\hline
\end{tabular}

\section{Results and Discussion}

In order to test the effectiveness of the minichannel cold-plate design, which is a commercially used thermal management design for prismatic Li-ion batteries, two-way coupled electrochemical-thermal simulations are performed at different discharge rates $(1-4 \mathrm{C})$ and coolant inlet temperatures $\left(15-35^{\circ} \mathrm{C}\right)$. The predicted battery voltage and thermal responses have been analyzed. Furthermore, the predicted temperatures at selected locations on the battery surface during the discharge process are compared with the measured data. The following sections briefly discuss the effects of coolant inlet temperature and discharge C-rate on the battery thermal response in terms of the heat generation and dissipation rates, the maximum surface temperature, and the temperature difference across the battery, along with key observations, which would help in better understanding the overall behavior of the BTMS.

\subsection{Battery Electrical Response}

Table 2 lists the input data used in the Li-ion model, popularly known as the pseudo2D (P2D) model available in COMSOL Multiphysics software exclusively for Li-ion batteries. Figures 5 and 6 show the Li-ion model simulated result of battery voltage variation in consideration at different C-rates and at an atmospheric temperature of $22^{\circ} \mathrm{C}$. It can be noted that the battery voltage drops faster as the $\mathrm{C}$-rate increases, and the battery discharge time is reduced significantly from its theoretical time (Figure 6). However, the initial drop in voltage at different $C$-rates is not observed with the $1 \mathrm{D}$ electrochemical battery model in contrast with the measured data, and the same can be attributed to the underlying assumptions such as no spatial variation in battery heat generation, constant property data, and a single layer consisting of cathode, anode, and separator is considered in spite of the battery having multi-layers. It can be noted here that a stop condition of $2.0 \mathrm{~V}$ is set in the $\mathrm{Li}$-ion model, and hence the discharge process terminates before the theoretical time of the corresponding battery load (current) used. Figure 7 shows that the Li-ion model predicted the power dissipation density of the $20 \mathrm{Ah} \mathrm{LiFePO}_{4}$ battery at different C-rates and at room temperature of $22{ }^{\circ} \mathrm{C}$. It can be observed that the battery heat generation rate increases linearly during the discharge process. However, it increases slowly at a low C-rate and rapidly at a high C-rate. 
Table 2. Li-ion model input data for $20 \mathrm{Ah} \mathrm{LiFePO}_{4}$ [34].

\begin{tabular}{lcc}
\hline \multicolumn{1}{c}{ Material Property (Unit) } & Positive Electrode & Negative Electrode \\
\hline Solid phase lithium diffusivity $\left(\mathrm{m}^{2} / \mathrm{s}\right)$ & $1 \times 10^{-13}$ & $3.9 \times 10^{-14}$ \\
\hline Particle radius $(\mathrm{m})$ & $12.5 \times 10^{-6}$ & $8 \times 10^{-6}$ \\
\hline Electrolyte phase volume fraction & 0.444 & 0.357 \\
\hline Electrode phase volume fraction & 0.297 & 0.471 \\
\hline Filler phase volume fraction & 0.259 & 0.172 \\
\hline Max solid phase concentration $\left(\mathrm{mol} / \mathrm{m}^{3}\right)$ & 22,806 & 31,370 \\
\hline $\begin{array}{l}\text { Initial concentration of active material } \\
\left(\text { mol/m }{ }^{3}\right)\end{array}$ & 14,870 & 14,870 \\
\hline Solid phase conductivity $(\mathrm{S} / \mathrm{m})$ & 3.8 & 100 \\
\hline Thickness $(\mu \mathrm{m})$ & 183 & 1000 \\
\hline & Other data & 1 \\
\hline Initial electrolyte salt concentration $\left(\mathrm{mol} / \mathrm{m}^{3}\right)$ & 52 \\
\hline Bruggeman coefficient & \\
\hline Thickness of separator $(\mu \mathrm{m})$ & \\
\hline
\end{tabular}

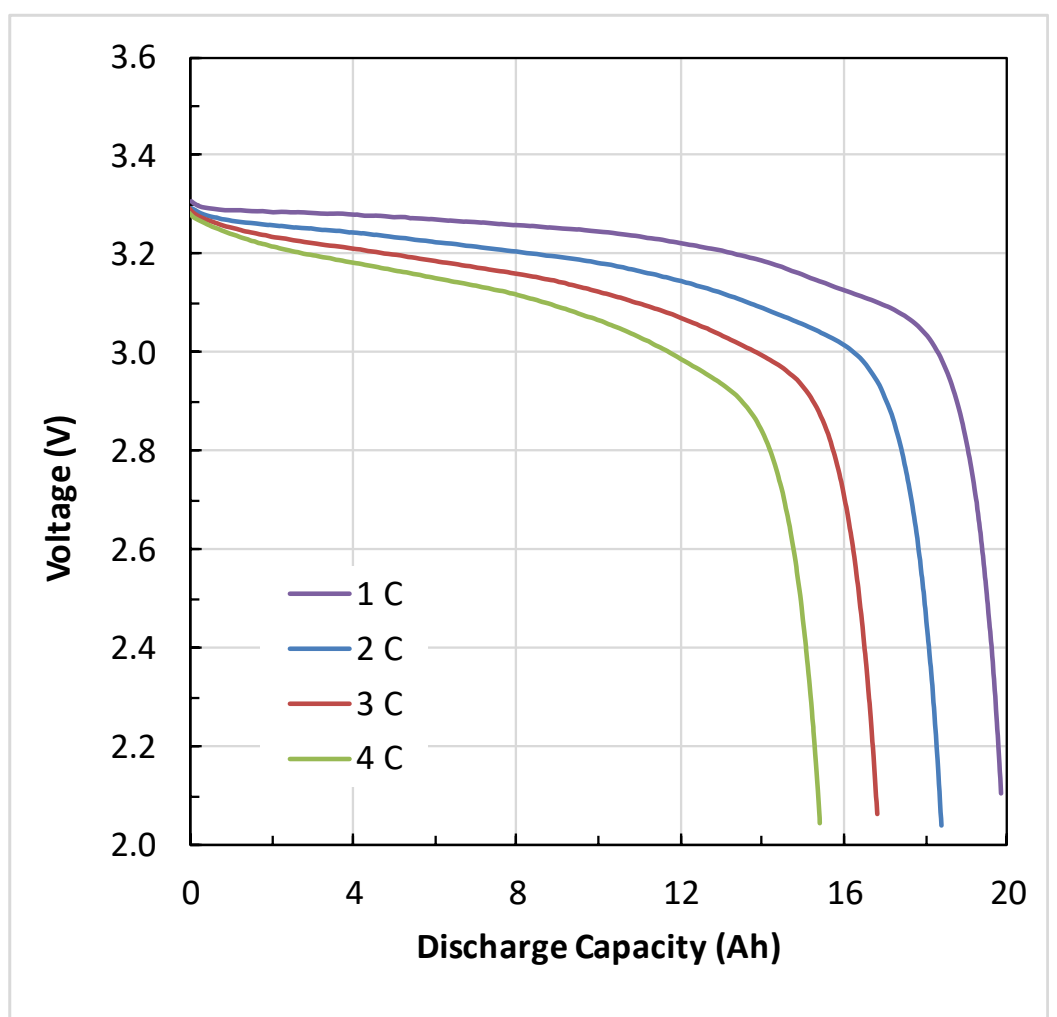

Figure 5. Predicted voltage-discharge capacity variation in $20 \mathrm{Ah} \mathrm{LiFePO}_{4}$ at different C-rates by Li-ion model. 


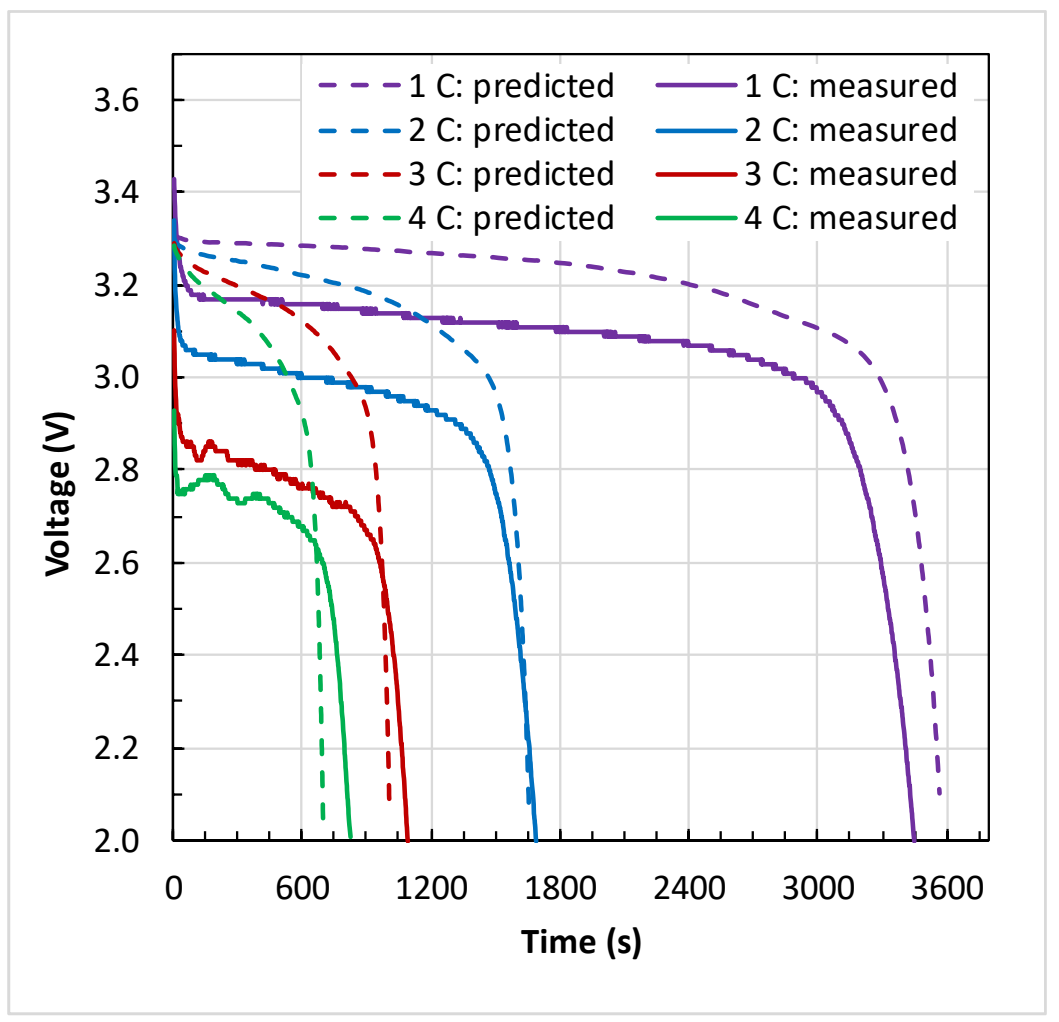

Figure 6. Predicted and measured discharge voltage-time response at different C-rates of $20 \mathrm{Ah}$ $\mathrm{LiFePO}_{4}$.

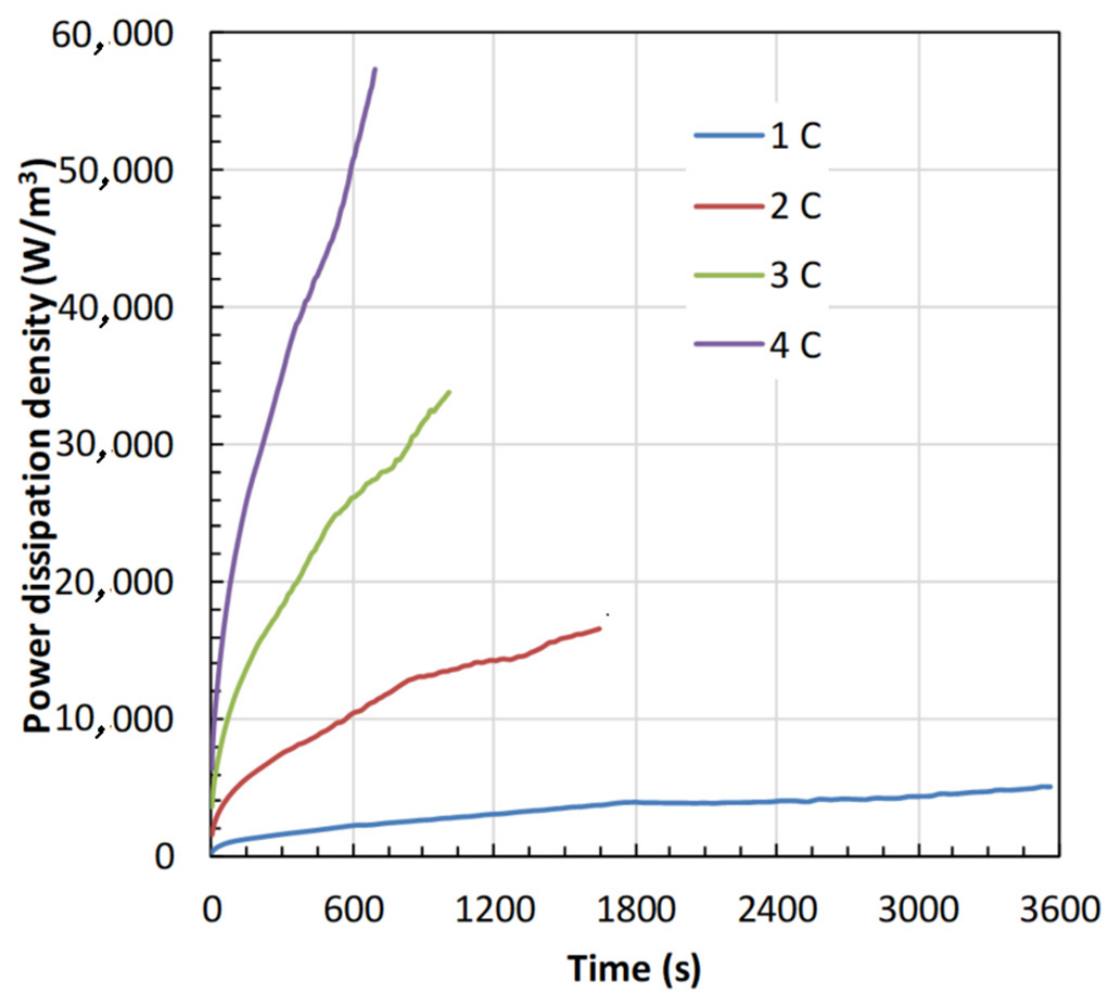

Figure 7. Predicted power density variation with time at different C-rates of $20 \mathrm{Ah}_{\mathrm{LiFePO}}$ by Li-ion model. 


\subsection{Battery Thermal Response}

The thermophysical property data for the $20 \mathrm{Ah} \mathrm{LiFePO}_{4}$ battery and cold-plate materials used in the simulations are given in Table 3. It can be noted that the property data given in Tables 2 and 3 are taken from the published experimental research works and compiled in the references $[33,34]$. Figure 8 shows the battery surface temperatures (maximum temperature, $T_{\max }$ and temperature difference, $\Delta T$ ) at the end of the discharge process with coolant inlet at $25^{\circ} \mathrm{C}$ and at different $\mathrm{C}$-rates. It is to be noted that the coolant inlet is on the left (anode side) and the exit is on the right (cathode side). The coolant flow rate through the individual channels considered in the present study is $150 \mathrm{~mL} / \mathrm{min}$, and it flows from the bottom left inlet on the anode side towards the bottom right exit of the cathode side with a single U-turn of individual channels. As the coolant flows inlet to the exit, water absorbs the heat energy and heats up, and hence the heat absorption capacity decreases in the flow direction. Therefore, it is obvious that battery temperatures would be higher on the cathode side and towards the coolant exit. The tabs on the battery heat up due to heat diffusion from the battery only, as the current flow through the tabs is not considered in the present study. Therefore, the cathode side tab temperature is less than battery surface temperature (near the coolant exit) in contrast to the reality wherein the current flow through the tabs results in higher temperatures due to additional internal heating. The difference in predicted values of $T_{\max }$ and $\Delta T$ can be observed from the colour contrast, as the upper temperature limit in the legend bar is fixed with respect to the highest $\mathrm{C}$-rate. For instance, at $1 \mathrm{C}$ discharge rate and $25{ }^{\circ} \mathrm{C}$ coolant inlet, the values of $T_{\text {max }}$ and $\Delta T$ are $26.44^{\circ} \mathrm{C}$ and $1.44^{\circ} \mathrm{C}$, respectively, while they are $36.88^{\circ} \mathrm{C}$ and $11.88^{\circ} \mathrm{C}$ at $4 \mathrm{C}$ discharge rate and $25^{\circ} \mathrm{C}$ coolant. Therefore, it is clear from Figure 8 that the $T_{\max }$ and $\Delta T$ (non-uniformity) increase with an increase in discharge rate and this is attributed to the increased heat generation due to an increase in load (current) on the battery.

Table 3. Thermophysical property data of $20 \mathrm{Ah} \mathrm{LiFePO}_{4}[34,35]$.

\begin{tabular}{cccc}
\hline Material/Property & Density $\left(\mathbf{k g} / \mathbf{m}^{\mathbf{3}}\right)$ & $\begin{array}{c}\text { Thermal } \\
\text { Conductivity } \\
\mathbf{( W / m - K )}\end{array}$ & $\begin{array}{c}\text { Specific Heat } \\
\text { (J/kg-K) }\end{array}$ \\
\hline Active battery & 2092 & 18.2 & 678 \\
\hline Positive tab & 2719 & 202.0 & 871 \\
\hline Negative tab & 8978 & 387.6 & 381 \\
\hline Cold-plate & 2702 & 237.0 & 903 \\
\hline
\end{tabular}

Ten different locations (a to $\mathrm{j}$ ) on the battery surface are selected to analyze the rate of rise in temperatures and the maximum temperature across the battery (see Figure 9). Anode side $(a, d, f)$, cathode side $(c, e, h)$, and middle $(b, g, i, j)$ are the three sets of locations. The rise in temperature during the constant current discharge procedure at various $\mathrm{C}$-rates is seen in Figure 10. The discharge process is considered in three phases in order to better understand the battery surface heating rate owing to heat generation: the beginning of discharge, the middle of discharge, and the end of discharge. It can be observed from Figure 10 that the temperatures increased continuously during the discharge process (all three phases) at all C-rates, with a very rapid increase in phase 1 . However, at a low C-rate $(1 \mathrm{C})$, the rate of rise in temperatures is distinct in all three phases with a plateau in phase 2 , while without a plateau at high C-rates $(2-4 \mathrm{C})$, which confirms that the heat generation rate is higher than the heat dissipation by the coolant and hence a sharp rise in temperatures at higher $\mathrm{C}$-rates. Additionally, at the end of the discharge process, the maximum surface temperatures on the anode side $(\mathrm{a}, \mathrm{d}, \mathrm{f})$ are lower than the temperatures of the cathode side $(\mathrm{c}, \mathrm{e}, \mathrm{h})$ and are consistent at all $\mathrm{C}$-rates. Moreover, the maximum temperatures are towards the coolant exit. 


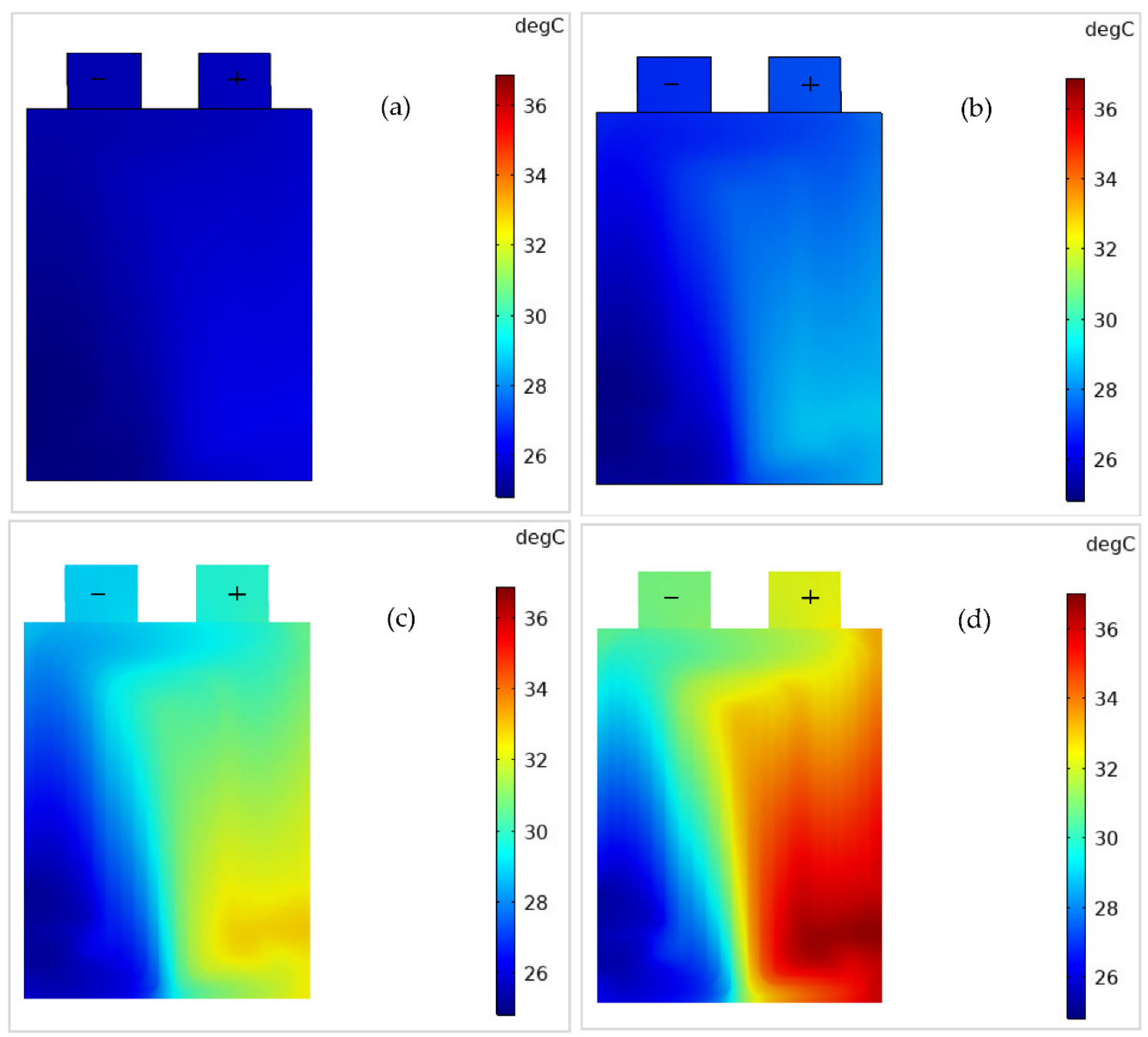

Figure 8. Predicted battery surface temperatures with minichannel cold-plate (water inlet at $25{ }^{\circ} \mathrm{C}$ ), and at different discharge rates; (a) 1 C (b) 2 C (c) 3 C (d) 4 C. 
Figures 11-13 show the comparison of predicted and measured rise in temperatures at five different locations $(f, g, h, i, j)$ during the discharge process at different $C$-rates $(2-4 \mathrm{C})$ and coolant inlet temperatures $\left(15-35^{\circ} \mathrm{C}\right)$. The above five locations are away from the tabs and are merely selected for a quantitative comparison with the measured temperature data. The temperatures measured at a low C-rate (2 C), shown in Figure 11, the rate of rise is rapid in phase 1 , and reduced in phase 2 , resulting in a plateau, and then increased in phase 3. The predicted maximum temperatures by the Li-ion model at the end of the discharge process are in close agreement with the measured values, except at low coolant inlet at $15^{\circ} \mathrm{C}$ and $2 \mathrm{C}$ (Figure 11a). However, the rate of rise in temperatures is not as much as that which is found with the measured data. With the increase in C-rates (3-4 C) and at all coolant inlet temperatures (Figures 12 and 13), the plateau in phase 2 vanished in the measured data (solid curves), and the same has been predicted by the present Li-ion model (dotted curves) as well. At $4 \mathrm{C}$ discharge rate and at all coolant inlet temperatures (Figure 13), the rise in temperature is rapid and continuous in all three phases of the discharge process, as shown by the measurements. The Li-ion model also predicted the trend, except that it over-predicted the temperatures across the battery surface. Table 4 provides the complete data on measured and predicted maximum temperatures and the temperature difference across the battery surface at all discharge rates (1-4 C) and coolant inlet temperatures $\left(15-35^{\circ} \mathrm{C}\right)$ undertaken in the present study. Based on Table 4 , the following quantitative observations can be drawn to show how effective the Li-ion model is to consider for the BTMS.

1. The maximum temperature $\left(T_{\max }\right)$ and the temperature difference $(\Delta T)$ across the battery surface rose with an increase in discharge $\mathrm{C}$-rate at the given coolant inlet temperature $\left(T_{w}\right.$, in $)$. At medium coolant inlet $\left(25^{\circ} \mathrm{C}\right)$, and at all $\mathrm{C}$-rates, the predicted values of $T_{\max }$ and $\Delta T$ are in good agreement with the measured values.

2. At low coolant inlet $\left(15^{\circ} \mathrm{C}\right)$, the Li-ion model under-predicted the values of $T_{\max }$ and $\Delta T$ at $1 \mathrm{C}$ and $2 \mathrm{C}$. However, at high coolant inlet $\left(35^{\circ} \mathrm{C}\right)$, the model slightly over-predicted the values $T_{\max }$ and $\Delta T$ at $4 \mathrm{C}$ in comparison to the measured values.

3. Furthermore, the percentage difference between the predicted and measured values of maximum surface temperature at all C-rates are within $2.6 \%$ at high coolant inlet $\left(35^{\circ} \mathrm{C}\right)$, within $4.8 \%$ at medium coolant inlet $\left(25^{\circ} \mathrm{C}\right)$, and within $14.6 \%$ at low coolant inlet $\left(15^{\circ} \mathrm{C}\right)$.

Table 4. Predicted vs. measured temperatures of a $20 \mathrm{Ah} \mathrm{LiFePO}_{4}$ battery with cold-plates.

\begin{tabular}{cccccc}
\hline \multirow{2}{*}{$\begin{array}{c}\text { Water Inlet } \boldsymbol{T} \\
\left({ }^{\circ} \mathbf{C}\right)\end{array}$} & $\begin{array}{c}\text { Discharge } \\
\text { C-Rate }\end{array}$ & $\begin{array}{c}\text { Maximum Battery Surface } \\
\text { Temperature, } \boldsymbol{T}_{\text {max }}\left({ }^{\circ} \mathbf{C}\right)\end{array}$ & \multicolumn{2}{c}{$\begin{array}{c}\text { Battery Surface Temperature } \\
\text { Difference, } \boldsymbol{\Delta} \boldsymbol{T}\end{array}$} \\
\cline { 3 - 5 } & & Experiments & $\begin{array}{c}\text { Li-ion } \\
\text { Model }\end{array}$ & Experiments & $\begin{array}{c}\text { Li-ion } \\
\text { Model }\end{array}$ \\
\hline 15 & 1 C & 19.6 & 16.74 & 4.0 & 1.74 \\
15 & 2C & 22.9 & 20.46 & 7.3 & 5.46 \\
15 & 3C & 25.4 & 25.49 & 9.8 & 10.49 \\
15 & 4 C & 28.0 & 31.14 & 12.4 & 16.14 \\
25 & 1C & 27.6 & 26.44 & 3.1 & 1.44 \\
25 & 2C & 30.4 & 29.3 & 5.9 & 4.3 \\
25 & 3C & 32.6 & 33.02 & 8.1 & 8.02 \\
25 & 4C & 35.2 & 36.88 & 10.7 & 11.88 \\
35 & 1 C & 35.9 & 36.13 & 2.4 & 1.13 \\
35 & 2C & 38.2 & 38.15 & 4.7 & 3.15 \\
35 & 3C & 40.3 & 40.17 & 6.8 & 5.17 \\
35 & 4 C & 42.3 & 43.38 & 8.8 & 8.38 \\
\hline
\end{tabular}




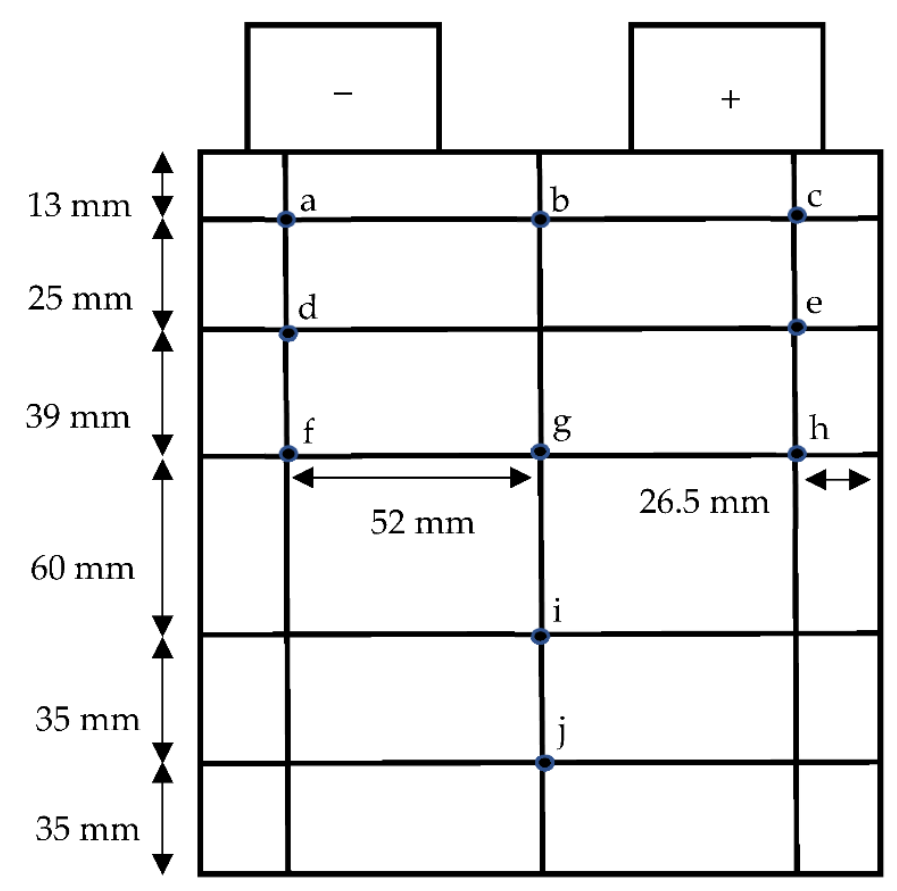

Figure 9. Ten different locations on battery surface.
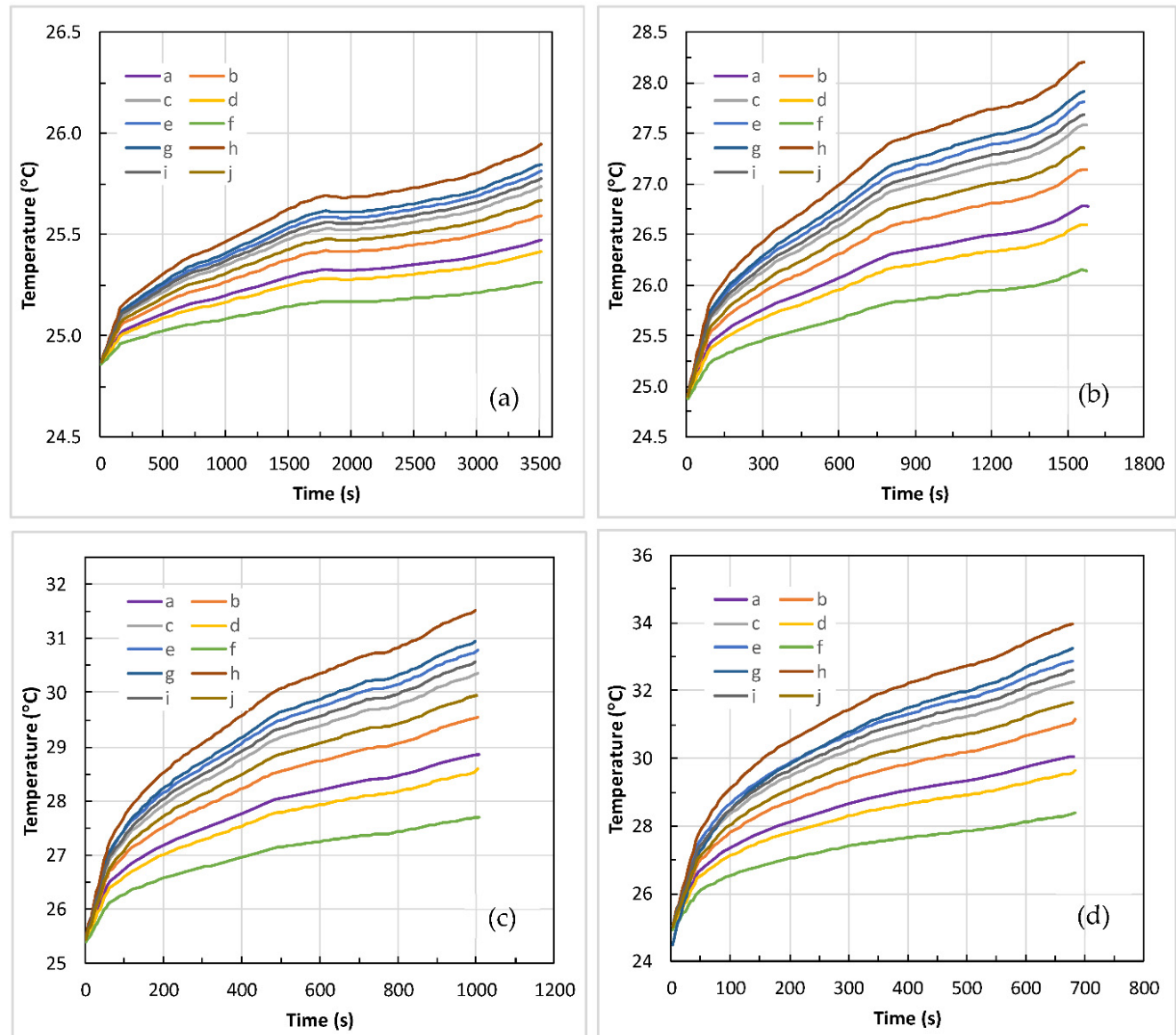

Figure 10. Predicted surface temperature variation at 10 different locations with water inlet at $25^{\circ} \mathrm{C}$ and at different discharge rates; (a) 1 C (b) 2 C (c) 3 C (d) 4 C. 

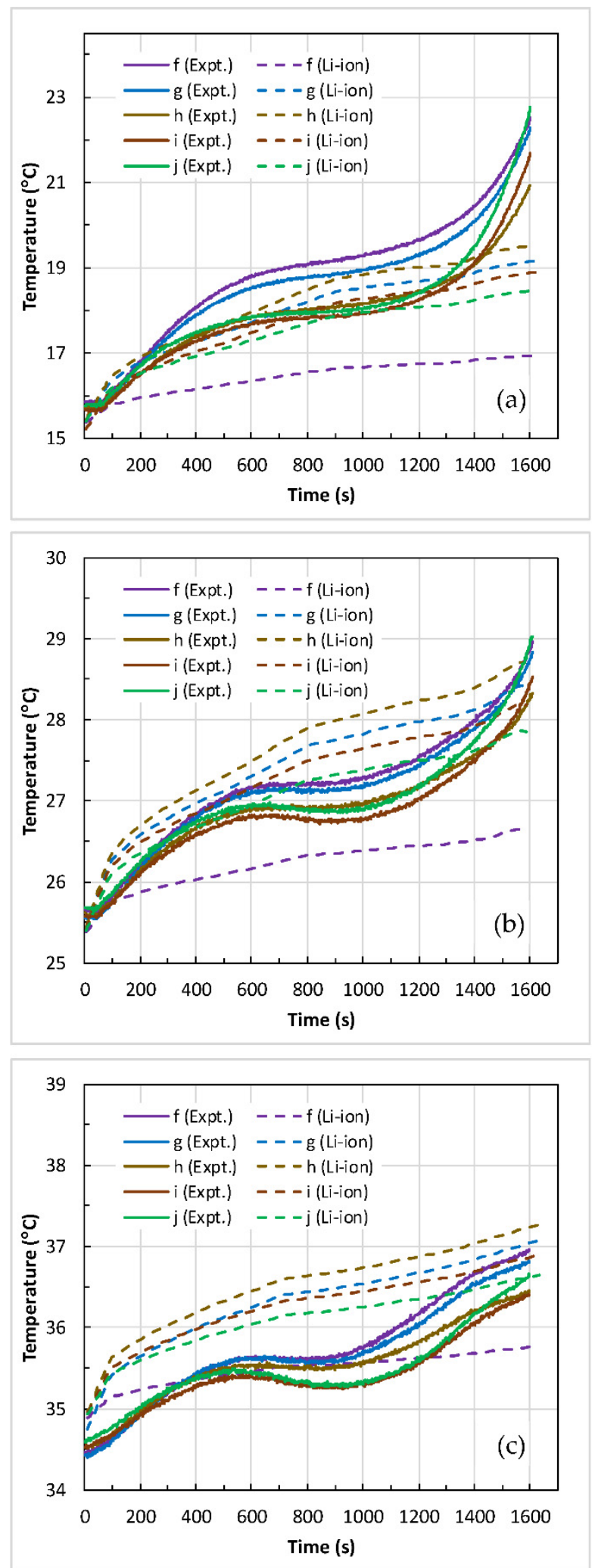

Figure 11. Predicted (dotted curves) and measured (solid curves) surface temperatures at 5 different locations at $2 \mathrm{C}$ discharge rate and at different coolant inlet temperatures; (a) $15^{\circ} \mathrm{C}$ (b) $25^{\circ} \mathrm{C}$ (c) $35^{\circ} \mathrm{C}$. 

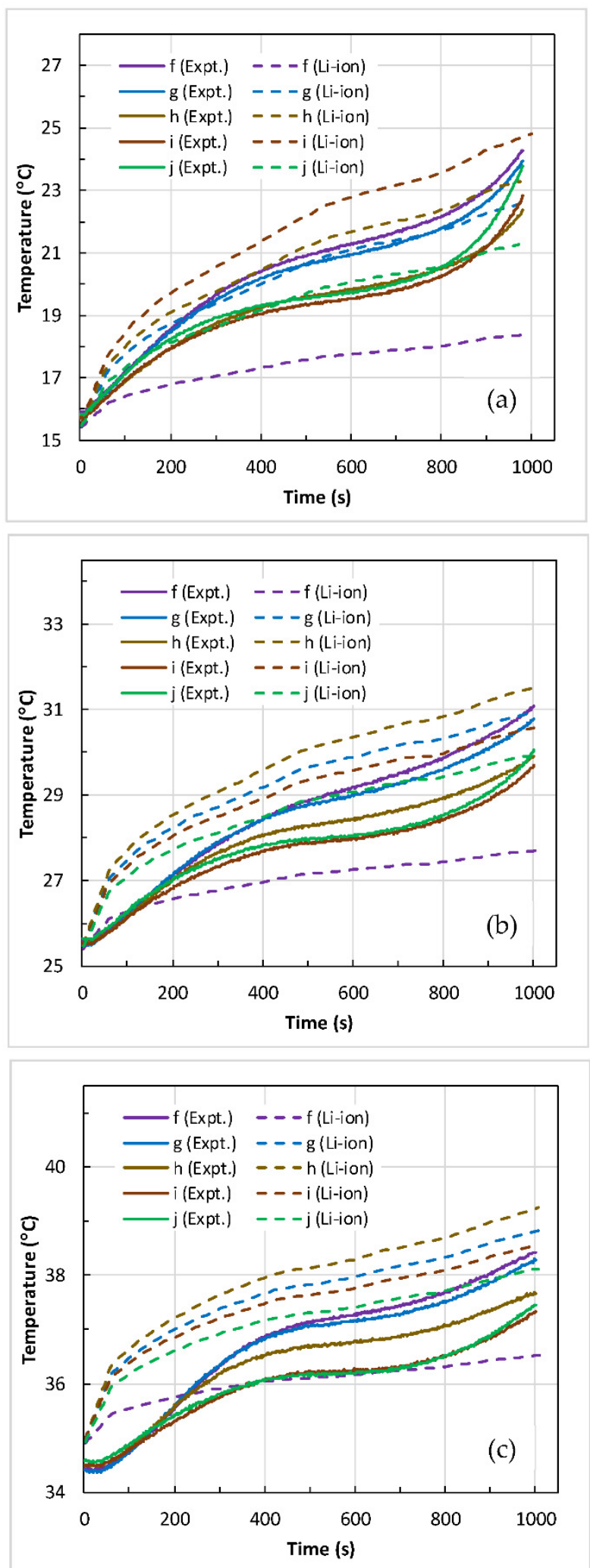

Figure 12. Predicted (dotted curves) and measured (solid curves) surface temperatures at 5 different locations at $3 \mathrm{C}$ discharge rate and at different coolant inlet temperatures; (a) $15^{\circ} \mathrm{C}$ (b) $25^{\circ} \mathrm{C}$ (c) $35^{\circ} \mathrm{C}$. 

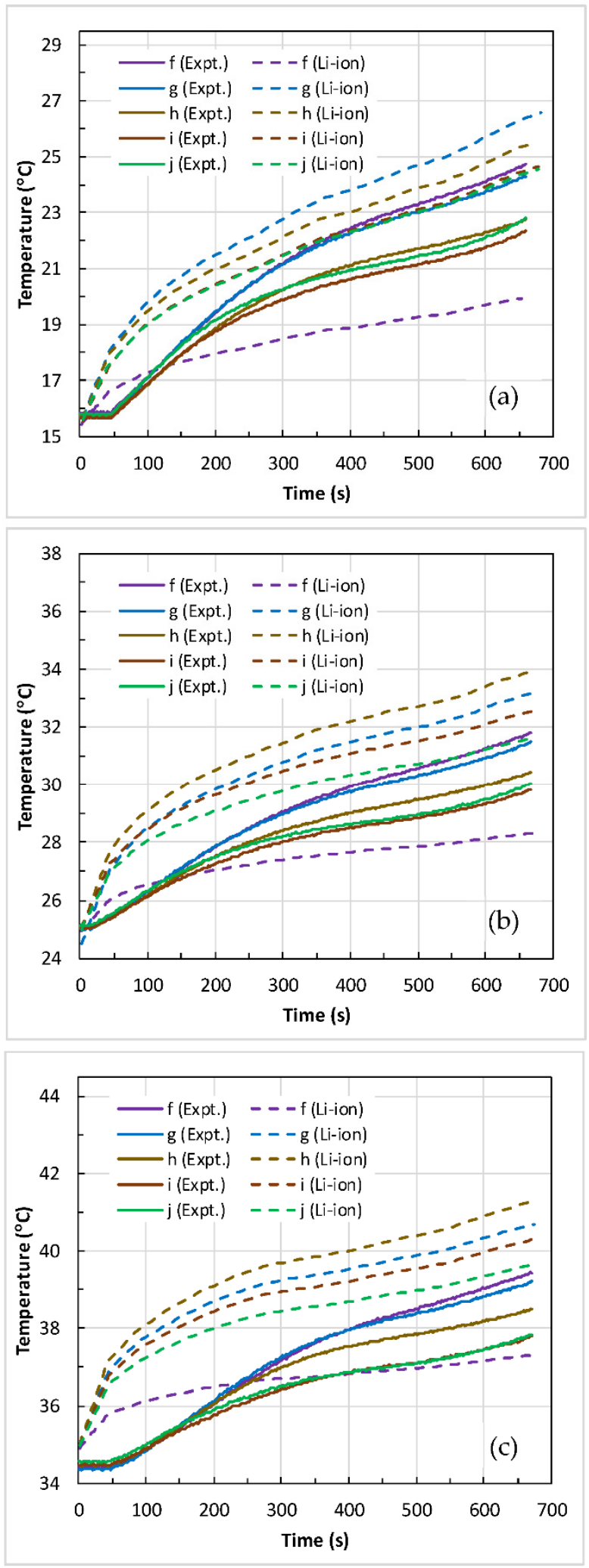

Figure 13. Predicted (dotted curves) and measured (solid curves) surface temperatures at 5 different locations at $4 \mathrm{C}$ discharge rate and at different coolant inlet temperatures; (a) $15^{\circ} \mathrm{C}$ (b) $25^{\circ} \mathrm{C}$ (c) $35^{\circ} \mathrm{C}$. 
Therefore, the above results clearly indicated that the performance of the current coolant design with distributed minichannel cold-plate water-cooling is effective for medium to high coolant inlet $\left(25-35^{\circ} \mathrm{C}\right)$ but not at low coolant inlet $\left(15^{\circ} \mathrm{C}\right)$. This could be due to a higher heat generation rate at low coolant inlet temperature. Interestingly, it is observed that at a given C-rate, $T_{\text {max }}$ increased linearly with an increase in $T_{w, i n}$. Additionally, at a given coolant temperature $\left(T_{w, i n}\right)$ the temperature difference $(\Delta T)$ increased with increase in discharge $C$-rate and is due to increased heat generation rate with increase in C-rates. However, $\Delta T$ decreased with increasing $T_{w, \text { in }}$ at all C-rates. Furthermore, increasing C-rates resulted in more non-uniformity in battery temperatures. Additionally, at all coolant inlet $T_{w, i n}$, the predicted temperature difference is less than $5^{\circ} \mathrm{C}$ at $1 \mathrm{C}$ and $2 \mathrm{C}$ discharge rates, and is about $8-16^{\circ} \mathrm{C}$ at $3 \mathrm{C}$ and $4 \mathrm{C}$ discharge rates. Thus, it can be concluded that the temperature uniformity across the battery surface primarily depends on the discharge C-rate and the coolant inlet temperature has a secondary effect, whereas the maximum temperature depends both on C-rate and coolant inlet temperature. Additionally, the present thermal management system (TMS) with distributed minichannel cold-plates is more suitable for $1-2 \mathrm{C}$ discharge rates and coolant inlet temperatures between $25-35{ }^{\circ} \mathrm{C}$, because the values of $T_{\max }$ and $\Delta T$ lie within the desired optimum working range $\left(T_{\max }\right.$ between $25-40{ }^{\circ} \mathrm{C}$ and $\Delta T<5{ }^{\circ} \mathrm{C}$ ).

\section{Summary}

In COMSOL software, a two-way coupled transient electrochemical-thermal model for a $20 \mathrm{Ah} \mathrm{LiFePO}_{4}$ battery sandwiched between two minichannel cold-plates with the distributed fluid flow has been created. The P2D Li-ion model calculates the instantaneous heat generation rate at the average battery temperature and feeds it into the 3D thermal model for the battery and cold-plates with fluid flow. Initially, the Li-ion model is evaluated at various C-rates (1-4 C) and room temperature $\left(22^{\circ} \mathrm{C}\right)$, and found that battery discharge capacity declines as C-rates rises. Following that, the effectiveness of the current BTMS is investigated in terms of heat generation rate, maximum temperature $\left(T_{\max }\right)$, and temperature difference $(\Delta T)$ across the battery surface at various discharge $C$-rates and water-coolant inlet temperatures $\left(T_{w, \text { in }}: 15-35^{\circ} \mathrm{C}\right)$. The predicted battery surface heating rate and end temperatures are also compared to the measured data at 10 different locations. The following are derived from the current research;

1. Both $T_{\max }$ and $\Delta T$ increase with an increase in the C-rate, and the rise in $T_{\max }$ is high at low $T_{w, \text { in }}$ in contrast to high $T_{w, i n}$, and is attributed to more heat generation at low $T_{w, i n}$.

2. $T_{\max }$ increases linearly with an increase in $T_{w, i n}$. However, $\Delta T$ is more (i.e., nonuniformity) at low $T_{w, i n}$ than at high $T_{w, i n}$.

3. Predicted temperatures are in close agreement with the measured data at $3 \mathrm{C}$ discharge rate. However, at low C-rates (1-2 C) the model slightly under-predicted the temperatures and slightly over-predicted at high C-rate $(4 \mathrm{C})$.

4. The current BTMS shows best performance meeting the desired operating range ( $T_{\max }: 25-40{ }^{\circ} \mathrm{C}, \Delta T<5^{\circ} \mathrm{C}$ ) at nominal discharge capacity $(1 \mathrm{C})$ and at all coolant temperatures studied.

Based on the above observations, the coupled electrochemical-thermal model predicted the effects of coolant inlet temperatures and discharge $C$-rates on $T_{\max }$ and $\Delta T$ across the battery surface as well as the battery surface heating rate, and are in close agreement with the measured data. The differences in the model predictions and measurements can be attributed to the assumption of homogenous reactions in the P2D model and uniform heat generation across the battery. Additionally, the Joule heating in the tabs is not considered in the present model. Furthermore, the constant input data pertaining to the electrochemical phenomena may also account for the percentage differences between the predicted and measured data. It can be concluded that the Li-ion model (P2D) available in COMSOL software can be used to design the (BTMS) at the cell level. However, to improve the battery model prediction accuracy, it is recommended to use the multi-layer approach instead of a 
single-layer approach, and a 3D electrochemical model with temperature spatial dependent electrochemical and thermal property data.

Author Contributions: Conceptualization, simulations and analysis, manuscript writing and editing; J.J., C.A. and S.D.C.; Experiments and data formatting; S.P. Supervision of the overall works; M.F. and R.F. All authors have read and agreed to the published version of the manuscript.

Funding: This research received no external funding. The APC is supported by the co-author, M. Fowler.

Institutional Review Board Statement: Not applicable.

Informed Consent Statement: Not applicable.

Data Availability Statement: Not applicable.

Acknowledgments: The authors from BITS Pilani, Hyderabad Campus would like to thank the institute management for providing the required computational resources.

Conflicts of Interest: The authors declare no conflict of interest.

\section{References}

1. Xia, G.; Cao, L.; Bi, G. A review on battery thermal management in electric vehicle application. J. Power Sources 2017, 367, 90-105. [CrossRef]

2. Shabani, B.; Biju, M. Theoretical modelling methods for thermal management of batteries. Energies 2015, 8, 10153-10177. [CrossRef]

3. Xie, Y.; Shi, S.; Tang, J.; Wu, H.; Yu, J. Experimental and analytical study on heat generation characteristics of a lithium-ion power battery. Int. J. Heat Mass Transf. 2018, 122, 884-894. [CrossRef]

4. Lai, Y.; Du, S.; Ai, L.; Ai, L.; Cheng, Y.; Tang, Y.; Jia, M. Insight into heat generation of lithium-ion batteries based on the electrochemical-thermal model at high discharge rates. Int. J. Hydrogen Energy 2015, 40, 13039-13049. [CrossRef]

5. Liu, G.; Ouyang, M.; Lu, L.; Li, J.; Han, X. Analysis of the heat generation of lithium-ion battery during charging and discharging considering different influencing factors. J. Therm. Anal. Calorim. 2014, 116, 1001-1010. [CrossRef]

6. Samba, A.; Omar, N.; Gualous, H.; Firouz, Y.; Van den Bossche, P.; Van Mierlo, J.; Boubekeur, T.I. Development of an advanced two-dimensional thermal model for large size lithium-ion pouch cells. Electrochim. Acta 2014, 117, 246-254. [CrossRef]

7. Jiang, F.; Peng, P.; Sun, Y. Thermal analyses of $\mathrm{LiFePO}_{4}$ /graphite battery discharge processes. J. Power Sources 2014, 243, 181-194. [CrossRef]

8. Chen, K.; Unsworth, G.; Li, X. Measurements of heat generation in prismatic Li-ion batteries. J. Power Sources 2014, 261 , 28-37. [CrossRef]

9. Drake, S.J.; Martin, M.; Wetz, D.A.; Ostanek, J.K.; Miller, S.P.; Heinzel, J.M.; Jain, A. Heat generation rate measurement in a Li ion cell at large C-rates through temperature and heat flux measurements. J. Power Sources 2015, 285, 266-273. [CrossRef]

10. Neupane, S.; Alipanah, M.; Barnes, D.; Li, X. Heat generation characteristics of $\mathrm{LiFePO}_{4}$ pouch cells with passive thermal management. Energies 2018, 11, 1243. [CrossRef]

11. Schuster, E.; Ziebert, C.; Melcher, A.; Rohde, M.; Seifert, H.J. Thermal behaviour and electrochemical heat generation in a commercial 40 Ah lithium-ion pouch cell. J. Power Sources 2015, 286, 580-589. [CrossRef]

12. Zhao, C.; Cao, W.; Dong, T.; Jiang, F. Thermal behavior study of discharging/charging cylindrical lithium-ion battery module cooled by channelled liquid flow. Int. J. Heat Mass Transf. 2018, 120, 751-762. [CrossRef]

13. Bahiraei, F.; Ghalkhani, M.; Fartaj, A.; Nazri, G. A pseudo 3D electrochemical-thermal modeling and analysis of a lithium-ion battery for electric vehicle thermal management applications. Appl. Therm. Eng. 2017, 125, 904-918. [CrossRef]

14. Jaguemont, J.; Boulon, L.; Dubé, Y. A comprehensive review of lithium-ion batteries used in hybrid and electric vehicles at cold temperatures. Appl. Energy 2016, 164, 99-114. [CrossRef]

15. Chalise, D.; Shah, K.; Halama, T.; Komsiyska, L.; Jain, A. An experimentally validated method for temperature prediction during cyclic operation of a Li-ion cell. Int. J. Heat Mass Transf. 2017, 112, 89-96. [CrossRef]

16. Munoz, P.M.; Humana, R.M.; Falaguerra, T.; Correa, G. Parameter optimization of an electrochemical and thermal model for a lithium-ion commercial battery. J. Energy Storage 2020, 13, 100387. [CrossRef]

17. An, Z.; Jia, L.; Wei, L.; Dang, C.; Peng, Q. Investigation on lithium-ion battery electrochemical and thermal characteristic based on electrochemical-thermal coupled mode. Appl. Therm. Eng. 2018, 137, 792-807. [CrossRef]

18. Deng, Y.; Feng, C.; Jiaqiang, E.; Zhua, H.; Chena, J.; Wen, M.; Yin, H. Effects of different coolants and cooling strategies on the cooling performance of the power lithium ion battery system: A review. Appl. Therm. Eng. 2018, 142, 10-29. [CrossRef]

19. Arora, S. Selection of thermal management system for modular battery packs of electric vehicles: A review of existing and emerging technologies. J. Power Sources 2018, 400, 621-640. [CrossRef]

20. Han, T.; Khalighi, B.; Yen, E.C.; Kaushik, S. Li-ion battery pack thermal management: Liquid vs. air cooling. J. Therm. Sci. Eng. Appl. 2019, 11, 021009. [CrossRef] 
21. Panchal, S.; Dincer, I.; Agelin-Chaab, M.; Fraser, R.; Fowler, M. Experimental and theoretical investigation of temperature distributions in a prismatic lithium-ion battery. Int. J. Therm. Sci. 2016, 99, 204-212. [CrossRef]

22. Panchal, S.; Khasow, R.; Dincer, I.; Agelin-Chaab, M.; Fraser, R.; Fowler, M. Numerical modelling and experimental investigation of a prismatic battery subjected to water cooling. Numer. Heat Transf. A 2017, 17, 626-637. [CrossRef]

23. Malika, M.; Dincer, I.; Rosen, M.A.; Mathew, M.; Fowler, M. Thermal and electrical performance evaluations of series connected Li-ion batteries in a pack with liquid cooling. Appl. Therm. Eng. 2018, 129, 472-481. [CrossRef]

24. Basu, S.; Hariharan, K.S.; Kolake, S.M.; Song, T.; Sohn, D.K.; Yeo, T. Coupled electrochemical thermal modelling of a novel Li-ion battery pack thermal management system. Appl. Energy 2016, 181, 1-13. [CrossRef]

25. Chalise, D.; Shah, K.; Prasher, R.; Jain, A. Conjugate heat transfer analysis of thermal management of a li-ion battery pack. Trans. ASME J. Electrochem. Energy Convers. Storage 2018, 15, 011008. [CrossRef]

26. Lan, C.; Xu, J.; Qiao, Y.; Ma, Y. Thermal management for high power lithium-ion battery by mini channel aluminum tubes. Appl. Therm. Eng. 2016, 101, 284-292. [CrossRef]

27. Wang, M.; Li, C.; Cui, N. Experimental investigation of water-cooling based thermal management for cylindrical li-ion batteries. In Proceedings of the IEEE 3rd Conference on Vehicle Control and Intelligence (CVCI), Hefei, China, 21-22 September 2019. [CrossRef]

28. Huo, Y.; Rao, Z.; Liu, X.; Zhao, J. Investigation of power battery thermal management by using mini-channel cold plate. Energy Convers. Manag. 2015, 89, 387-395. [CrossRef]

29. Alipoura, M.; Esena, E.; Kizilelb, R. Investigation of 3-D multi-layer approach in predicting the thermal behavior of $20 \mathrm{Ah} \mathrm{Li}$-ion cells. Appl. Therm. Eng. 2019, 153, 620-632. [CrossRef]

30. Liu, K.; Li, K.; Peng, Q.; Zhang, C. A brief review on key technologies in the battery management system of electric vehicles. Front. Mech. Eng. 2019, 14, 47-64. [CrossRef]

31. Panchal, S. Experimental Investigation and Modeling of Lithium-Ion Battery Cells and Packs for Electric Vehicles. Ph.D. Thesis, University of Ontario Institute of Technology, Oshawa, ON, Canada, 2016. Available online: http://ir.library.dc-uoit.ca/handle/ 10155/747 (accessed on 10 February 2021).

32. Panchal, S. Impact of Vehicle Charge and Discharge Cycles on the Thermal Characteristics of Lithium-Ion Batteries. Master's Thesis, University of Waterloo, Waterloo, ON, Canada, 2014. Available online: http://hdl.handle.net/10012/8423 (accessed on 10 February 2021).

33. Battery Design Module User's Guide, COMSOL Multiphysics®v.5.6; COMSOL AB: Stockholm, Sweden, 2020; pp. 231-371. Available online: https:/ / doc.comsol.com/5.6/doc/com.comsol.help.battery / BatteryDesignModuleUsersGuide.pdf (accessed on 10 February 2021).

34. Panchal, S.; Dincer, I.; Agelin-Chaab, M.; Fraser, R.; Fowler, M. Transient electrochemical heat transfer modelling and experimental validation of a large sized $\mathrm{LiFePO}_{4}$ /graphite battery. Int. J. Heat Mass Transf. 2017, 109, 1239-1251. [CrossRef]

35. Patil, M.S.; Seo, J.; Panchal, S.; Jee, S.; Lee, M. Investigation on thermal performance of water-cooled Li-ion pouch cell and pack at high discharge rate with U-turn type microchannel cold plate. Int. J. Heat Mass Transf. 2020, 155, 119728. [CrossRef] 